\title{
MATRIMONIOS CELEBRADOS EN EL EXTRANJERO E INSCRIPCIÓN EN EL REGISTRO CIVIL: PRÁCTICA DE LA DIRECCIÓN GENERAL DE LOS REGISTROS Y DEL NOTARIADO
}

\author{
Mónica GuZMÁn ZaPATER *
}

SUMARIO: 1. INTRODUCCIÓN.-2. LA INSCRIPCIÓN REGISTRAL.-2.1. Régimen jurídico de la inscripción registral.-2.2. Inscripción y reconocimiento.-2.3. Títulos inscribibles.-2.3.1. Inscripción sin expediente (art. 256.3 RRC).-2.3.2. Inscripciones que requieren la formación de expediente (art. 257 RRC).-2.4. Denegación de la inscripción.-3. PRACTICA DE LA DIRECCIÓN GENERAL DE LOS REGISTROS Y DEL NOTARIADO.-3.1. Control sobre la forma de celebración.-3.1.1. Falta de idoneidad del título.-3.1.2. Matrimonios coránicos.-3.1.3. Matrimonios consuetudinarios.-3.1.4. Matrimonio en forma canónica.-3.2. Control sobre la capacidad nupcial.-3.2.1. Menor de edad.-3.2.2. Subsistencia de vínculo matrimonial anterior--3.2.3. Poligamia.-3.3. Control sobre el consentimiento matrimonial.-3.3.1. Matrimonios acordados.-3.3.2. Matrimonios simulados.-3.3.3. Celebración del matrimonio fuera y posterior nacionalización española de uno de los cónyuges.-3.3.4. Matrimonios por poder (art. 258 RRC).-4. CONCLUSIÓN.

\section{INTRODUCCIÓN}

1. La caracterización del derecho a contraer matrimonio como un derecho fundamental (arts. 16 DUDH ${ }^{1}$ y $32.1 \mathrm{CE}$ ), de configuración legal (art. 32.1 $\mathrm{CE})^{2}$ sitúa la institución matrimonial como un negocio jurídico del Derecho

* El presente trabajo se enmarca en el Proyecto financiado por la Secretaría de Estado de Investigación, Desarrollo e Innovación DER2014-54470-P (2015/2018) sobre La regulación de las crisis matrimoniales internacionales. Mónica Guzmán Zapater es catedrática de Derecho internacional privado en la UNED(mguzman@der.uned.es).

1 Art. 16 DUDH: «1. Los hombres y las mujeres, a partir de la edad núbil, tienen derecho, sin restricción alguna por motivos de raza, nacionalidad o religión, a casarse y fundar una familia; y disfrutarán de iguales derechos en cuanto al matrimonio, durante el matrimonio y en caso de disolución del matrimonio. 2. Solo mediante libre y pleno consentimiento de los futuros esposos podrá contraerse el matrimonio».

2 Sobre la configuración del matrimonio en la doctrina constitucional, Pérez VerA, E., Las relaciones de familia en la doctrina del Tribunal Constitucional, Granada, Real Academia de Jurisprudencia y Legislación de Granada, 2016. Cfr. GARcía RodRíGUEZ, I., La celebración del matrimonio religioso no católico, Madrid, Tecnos, 1999, pp. 273 y 274. 
de familia cuya validez está subordinada al cumplimiento de tres presupuestos: la capacidad para contraerlo, la prestación de un consentimiento y ante una determinada autoridad (art. $49 \mathrm{CC})^{3}$. La inscripción registral no es constitutiva pues se admite que los efectos derivan del hecho mismo de la celebración, si bien es preceptiva para que el matrimonio produzca plenos efectos jurídicos (art. 61.1 CC). Los tres presupuestos previstos en la regulación interna (arts. 42 a 80 CC) se proyectan asimismo sobre los supuestos internacionales caracterizados por la presencia de un elemento extranjero. Este puede venir determinado en los supuestos de celebración en España, por la distinta nacionalidad de las partes y en los supuestos de celebración en el extranjero por el hecho mismo de la celebración ante autoridad extranjera al margen de que uno de los contrayentes pueda ostentar además una nacionalidad distinta de la española.

2. La comprobación de los requisitos relativos a la validez del matrimonio celebrado en España tiene lugar antes de la celebración por el expediente previo. En los supuestos de celebración en el extranjero ante autoridad civil o religiosa, la verificación de la capacidad así como la intervención de una autoridad local en la recepción de los consentimientos tiene lugar en el momento de la inscripción del matrimonio en el Registro Civil (arts. 256 y 257 RRC). Y esto porque junto al documento a aportar como prueba del matrimonio conforman el título las «declaraciones complementarias» de los contrayentes.

3. El sistema matrimonial español parte de una apariencia de legalidad de tales matrimonios dado que legalmente el control solo alcanza a la intervención de una autoridad extranjera (art. 49.2 CC). Sin embargo, con dudoso respeto al principio de jerarquía normativa, es la legislación registral —y la práctica de la DGRN - la que agrega el control sobre el consentimiento y la capacidad de los contrayentes, en la medida en que no es deseable que accedan al Registro Civil español matrimonios potencialmente nulos conforme a la legislación española o que infrinjan normas imperativas ${ }^{4}$. Debe recordarse, asimismo, que el sistema matrimonial español adolece de una laguna legal en cuanto a la ley que deba determinar la validez del consentimiento y capacidad de los contrayentes en los supuestos vinculados con ordenamientos extranjeros. Laguna que no se ha colmado en las sucesivas reformas, si bien parece asentada la doctrina conforme a la cual al tratarse de cuestiones de estado civil corresponde a la norma de conflicto general en la materia (art. 9.1 CC) y a la ley personal de los contrayentes decidir acerca de estas cuestiones. Únicamente la excepción de orden público, cada vez

3 De conformidad con lo exigido por el Convenio NU de 10 de diciembre de 1962 sobre el consentimiento para el matrimonio, la edad mínima para el matrimonio y el registro para el matrimonio. Art. 1.1. «No podrá contraerse legalmente matrimonio sin el pleno y libre consentimiento de ambos contrayentes, expresado por estos en persona, después de la debida publicidad, ante la autoridad competente para formalizar el matrimonio y testigos, de acuerdo con la ley».

${ }^{4}$ Cfr. Arenas García, R., Crisis matrimoniales internacionales. Nulidad, separación y divorcio en el nuevo Derecho internacional privado español, Santiago de Compostela, De Conflictu Legum, Universidad de Santiago de Compostela, 2004, p. 236. 
que se produzca una infracción de derechos fundamentales, puede justificar la inaplicación de la ley designada y la aplicación sustitutiva de la ley española.

4. Dos son los objetivos particulares que se derivan de la caracterización del derecho a contraer matrimonio como derecho fundamental: en primer término, la seguridad jurídica en cuanto al status matrimonial, y en segundo lugar el favor matrimonii, pues como pusiera de relieve Julio D. González Campos, la ordenación legal ha de facilitar el matrimonio en consonancia con el reconocimiento del derecho fundamental ${ }^{5}$. Pues bien, cabe comprobar cómo la excepción de orden público se activa con mucha frecuencia, casi mecánicamente, en la fase con control de validez del matrimonio celebrado ante autoridad extranjera ${ }^{6}$. Nosotros hemos examinado parte de la práctica de la DGRN cuando este órgano de la Administración se pronuncia sobre los recursos planteados contra las resoluciones dictadas por los encargados de los Registros Civiles competentes ante los que se promueve la inscripción del matrimonio. Destaca su importancia en número - dato que sin duda dificulta la tarea de la DGRN-y un incremento constante de supuestos de denegación de la inscripción, en una actuación que en ocasiones parece condicionada por la actual política de extranjería. Desde esta perspectiva hace tiempo que se denunció con acierto la evidencia de una preocupación real «por la protección de fronteras más que por la protección de la institución matrimonial» ${ }^{7}$, idea crítica expandida en la doctrina ${ }^{8}$. El hecho es que hace más de cinco años que la concesión de visados está cerrada y, salvo excepciones, únicamente se expiden en el marco de la política de reagrupación familiar ${ }^{9}$. Incluso dentro de este marco, la doctrina también se cuestiona la propia legalidad de la exigencia de inscripción registral del matrimonio celebrado en el extranjero para la reagrupación familiar por matrimonio ${ }^{10}$, al provocar enormes retrasos para la obtención del visado, resultando tanto más pernicioso si el

5 Cfr. GonZález CAmpos, J. D., «Derecho de familia. El matrimonio», en VVAA, Derecho internacional privado. Parte especial, Madrid, Eurolex, 1995, p. 296. Bien es cierto que al tratarse de un derecho fundamental de configuración legal y no absoluto, admite que el legislador introduzca modificaciones y restricciones que han de ser proporcionales al fin perseguido.

6 Como contrapunto hace menos de veinte años a partir de un examen de la práctica de la DGRN y de los Tribunales, la doctrina detectaba una prevalencia del ius nubendi como valor en alza, siendo el orden público interpretado restrictivamente (véase AgUILAR BENÍTEZ DE LUGO, M., «Ius nubendi y orden público matrimonial», Boletín de Información, 1 de febrero de 2000, núm. 1.862, Ministerio de Justicia, pp. 425-447).

7 Cfr. SÁnchez Lorenzo, S., "La inconveniente doctrina de la DGRN acerca de los matrimonios de conveniencia», en VVAA, Derecho registral internacional. Homenaje a la memoria del profesor Rafael Arroyo Montero, Madrid, 2003, pp. 247-285, esp. pp. 266-273.

8 Orejudo Prieto De los Mozos, P., «Prevención de matrimonios fraudulentos celebrados en el extranjero», AEDIPr, 2008, pp. 1158-1160.

9 Sobre la relación entre el estatuto de extranjería y el Derecho internacional privado, véase VARGas Gómez URRutia, M., La reagrupación familiar de los extranjeros en España, Madrid, Thomson Aranzadi, 2006, esp. pp. 320-347.

10 Martín ConsarnaU, D., «El documento público extranjero en el procedimiento de extranjería y la exigencia de inscripción del matrimonio mixto celebrado ante autoridad extranjera», en FonT I MAS, M. (dir.), El documento público extranjero en España y en la Unión Europea: Estudios sobre las características y efectos del documento público, 2014, pp. 333-357, esp. pp. 348-353. 
trámite previo de inscripción desemboca en denegación. En suma, una privación de derechos a personas a quienes les corresponden.

5. El objeto de este trabajo es el estudio de la práctica de la DGRN tomando como punto de partida el año 2000. Por los límites que impone un trabajo de estas características no se pretende una reconstrucción dogmática de la problemática del reconocimiento de los matrimonios celebrados en el extranjero ${ }^{11}$. Tampoco una exposición exhaustiva de todas las resoluciones de la DGRN. Se han seleccionado muchas, imposible todas, dada la diversidad de modelos matrimoniales que complica la tarea de abordar todos los problemas planteados en la práctica de la inscripción. De modo que vaya por delante que como toda selección tiene algo de arbitrario, nuestro objetivo es contrastar dónde residen las dificultades al promover la inscripción en el Registro Civil de un matrimonio celebrado ante autoridad extranjera y cuáles son las líneas seguidas por la $\mathrm{DGRN}^{12}$. A este fin recordaremos en una primera parte las principales cuestiones que suscita el régimen jurídico de la inscripción registral, y en una segunda procederemos al examen de la práctica ordenada en su exposición según que los problemas deriven de la forma o de los requisitos de fondo del matrimonio.

\section{LA INSCRIPCIÓN REGISTRAL}

6. Recordemos los elementos claves para promover la inscripción en el Registro Civil de los matrimonios celebrados ante autoridad extranjera.

\subsection{Régimen jurídico de la inscripción registral}

7. La regla general de competencia territorial se contiene en el art. 16.1 de la Ley del Registro Civil vigente (en adelante, «LRC») al disponer que «la inscripción de los nacimientos, matrimonios y defunciones se inscribirán en el Registro municipal o Consular del lugar en que acaezcan» y disposiciones complementarias. En suma, buena parte de los matrimonios celebrados ante autoridad extranjera se inscriben en los Registros consulares por corresponder con el lugar de celebración (arts. 16.1 LRC y 68. 1 del Reglamento del Registro Civil, en adelante «RRC»). Adicionalmente la competencia corresponde al Registro Civil Central cuando la inscripción no pueda promoverse en el extranjero por razones excepcionales (art. 18 LRC) o cuando el promotor tenga su domicilio en España (art. 68.2 RRC).

8. Para la práctica de la inscripción de los matrimonios celebrados en el extranjero, en la legislación registral vigente — mientras no entre en vigor

11 Mérito que por rigor y exhaustividad corresponde a OreJudo PRIETO DE LOS Mozos, P., La celebración y el reconocimiento de la validez del matrimonio en Derecho internacional privado español, Pamplona, Aranzadi, 2003.

${ }_{12}$ Excluimos, por tanto, con una sola excepción, el análisis de la jurisprudencia de los tribunales, aunque parece desproporcionadamente baja la litigiosidad en ese ámbito. 
la Ley 20/2011, de 21 de julio, de Registro Civil— las disposiciones clave son los arts. 256.3 y 257 RRC. El primero permite la inscripción del matrimonio contenido en certificación extranjera y el segundo, a falta de certificación, requiere la formación de un expediente. Complementariamente hay que tener en cuenta la Orden del Ministerio de Justicia 577/2016, de 19 de abril, sobre inscripción en el Registro Civil de determinados matrimonios celebrados en forma religiosa y aprobación del modelo de certificado de capacidad matrimonial y de celebración de matrimonio religioso ${ }^{13}$ por la que se deroga la Instrucción DGRN, de 10 de febrero de 1993, sobre la inscripción en el Registro Civil de determinados matrimonios celebrados en forma religiosa ${ }^{14}$; la Instrucción-Circular de 29 de julio de 2005, sobre matrimonios civiles entre personas del mismo sexo ${ }^{15}$; la Instrucción de 31 de enero de 2006, sobre los matrimonios de complacencia; además de la Instrucción de 20 de marzo de 2006, sobre prevención del fraude documental en materia de estado civil ${ }^{16}$.

\subsection{Inscripción y reconocimiento}

9. El valor de la práctica de la DGRN es absoluto en este sector. Cuando hoy se alude al reconocimiento e inscripción registral del matrimonio celebrado en el extranjero, se designa una realidad sumamente compleja y variada en los sustratos fácticos a los que la DGRN va dando respuesta. Inscripción y reconocimiento de la validez del matrimonio no deben confundirse. El sistema español hace preceptiva la inscripción registral (art. 61.1 CC), de modo que coloca al encargado del Registro en la posición central en orden a verificar la validez del matrimonio celebrado ante autoridad extranjera. La norma básica del sistema de inscripción de los matrimonios celebrados por españoles ante autoridad extranjera civil o religiosa, en el extranjero, es la que establece que:

«También podrá contraer matrimonio fuera de España con arreglo a la forma establecida por la ley del lugar de celebración» (art. 49.2 CC).

10. La idea sobre la que se sustenta la viabilidad de la inscripción en un Registro Civil es que si el matrimonio se contrajo válidamente ante autoridad extranjera civil o religiosa, la legislación española facilita la continuidad del matrimonio. Es un control sobre la autoridad interviniente. Si es válido para el ordenamiento de aquel lugar, en forma civil o religiosa prevista por aquella ley, hay una apariencia de validez. Ahora bien, es un sistema que hace que resulte disponible para los contrayentes la forma de celebración - dado que se admite la que sea conforme con la lex loci-, pero indisponible o imperativo en cuanto a los requisitos de fondo: capacidad y consentimiento. Aun cuando

13 BOE de 22 de abril de 2016.

4 BOE de 24 de febrero de 1993

$15 B O E$ de 8 de agosto de 2005.

16 BOE de 4 de abril de 2006. 
en principio ambas cuestiones en la teoría y en la práctica quedarían sujetas a la ley personal (extranjera) del contrayente extranjero ${ }^{17}$, otra práctica constante con apoyo doctrinal ${ }^{18}$ revela que la regulación española ha tomado una deriva imperativa en torno a estos dos aspectos esenciales del matrimonio necesariamente sujetos a la ley española.

11. La inscripción en el Registro Civil es relevante al ser un último filtro de control de validez del matrimonio. La garantía de legalidad del Registro Civil obliga a un control de legalidad mediante la potestad calificadora del registrador ${ }^{19}$. Aunque en principio el sistema parte de que los contrayentes pueden acogerse sin restricciones a las formas locales extranjeras, el control de validez conforme a la ley española y de concordancia con la realidad no está limitado y lo incluye todo: capacidad nupcial, existencia y validez del consentimiento y autoridad competente celebrando en la debida forma. Se requiere pues que mediante la calificación del documento aportado y las declaraciones complementarias oportunas el encargado del Registro llegue a la convicción de que no hay dudas acerca de la realidad del hecho y la legalidad conforme a la ley española ${ }^{20}$.

12. En esta fase el encargado del Registro debe proceder al contraste de todos los aspectos de forma y fondo del matrimonio (art. $65 \mathrm{CC})^{21}$ : que la celebración ha tenido lugar ante autoridad local competente, siendo válido conforme a la ley local; que los contrayentes son capaces conforme a su ley personal, siempre que dicha ley no contradiga el orden público español; que han prestado un consentimiento matrimonial veraz.

17 Cfr. González Campos, J. D., op. cit., nota 5, p. 311. Tiene importancia que así se afirme en la Instrucción DGRN de 10 de febrero de 1993, sobre inscripción en el Registro Civil de determinados matrimonios celebrados en forma religiosa (Regla IV).

18 En este sentido, Luces GIL, F., Derecho del registro civil, Barcelona, Bosch, 2002, p. 238; OTERO GARCíA-CASTRILLON, C., "La capacidad y la simulación en el matrimonio: fraude y extranjería en la doctrina de la DGRN», en VVAA, Derecho registral internacional. Libro Homenaje a la memoria del profesor Rafael Arroyo Montero, Madrid, 2003, p. 289, nota 14.

19 Se ha dicho que el control de legalidad actúa en tres direcciones, de las que hay que poner de relieve dos: veta el acceso al Registro Civil de los actos inexistentes, inválidos o ineficaces dotando al encargado de poderes de calificación; le permite adoptar cautelas tendentes a garantizar la exactitud de los hechos inscribibles (cfr. DíAz FraILE, J. M., «Breve esbozo de una teoría general sobre los principios registrales civiles. Particular estudio de la publicidad material del Registro civil», Revista Crítica de Derecho Inmobiliario, año 78, 2002, núm. 672, pp. 1367-1404, esp. pp. 1370-1371).

20 Esto es así desde la RDGRN de 30 de mayo de 1995; y se reafirma, entre otras muchas, en las RRDGRN (2. $)$ de 2 de julio de 2009 y (29. ${ }^{\text {a }}$ de 10 de mayo de 2012; asimismo, Instrucción DGRN de 31 de enero de 2006, sobre matrimonios de complacencia, BOE de 22 de marzo de 2006, cfr. Regla VIII.

21 Conforme al art. 65 CC: «1. En los casos en que el matrimonio se hubiere celebrado sin haberse tramitado el correspondiente expediente o acta previa, si este fuera necesario, el Secretario judicial, Notario, o el funcionario diplomático o consular encargado del Registro Civil que lo haya celebrado, antes de realizar las actuaciones que procedan para su inscripción, deberá comprobar si concurren los requisitos legales para su validez, mediante la tramitación del acta o expediente al que se refiere este artículo. 2. Si la celebración del matrimonio hubiera sido realizada ante autoridad o persona competente distinta de las indicadas en el párrafo anterior, el acta de aquella se remitirá al encargado del Registro Civil del lugar de celebración para que proceda a la comprobación de los requisitos de validez, mediante el expediente correspondiente. Efectuada esa comprobación, el encargado del Registro Civil procederá a su inscripción». 


\subsection{Títulos inscribibles}

13. Tiene que darse una apariencia de validez del matrimonio para que se pueda promover la inscripción acreditada a través de un documento que sirva de título para acceder al Registro ${ }^{22}$. La inscripción se condiciona al reconocimiento del título presentado, esto es, a su eficacia conforme a Derecho español. Las pautas de actuación están contenidas sobre todo en la Instrucción de 31 de enero de $2006^{23}$.

14. La inscripción del matrimonio celebrado en el extranjero se puede activar a través de dos mecanismos alternativos. Bien a través de certificación extranjera en la que conste la celebración del matrimonio y las «declaraciones complementarias», lo que constituye la regla general; bien en su defecto, a través del expediente registral para acreditar la legalidad del matrimonio y la certeza de su celebración ${ }^{24}$. Luego puede practicarse mediante certificación expedida por autoridad o funcionario del país de celebración (art. 256.3 RRC) o en virtud de expediente (art. 257 RRC) ${ }^{25}$. No está claro, sin embargo, qué supuestos van por el art. 256.3 RRC y cuáles pueden acceder por el art. 257 RRC.

\subsubsection{Inscripción sin expediente (art. 256.3 RRC)}

15. En principio si hay documento y no hay dudas sobre la realidad del hecho y de su legalidad conforme a la ley española, debiera bastar la certificación expedida por la autoridad extranjera o por la correspondiente confesión religiosa como título para practicar la inscripción ${ }^{26}$. La inscripción se practicará en virtud de un doble título:

«La inscripción del matrimonio celebrado en el extranjero requiere la aportación de la certificación de la autoridad extranjera por autoridad o funcionario

22 Cfr. EsPINAR ViCEnTE, J. M., El matrimonio y las familias en el sistema español de Derecho internacional privado, Madrid, Civitas, 1996, p. 170.

${ }^{23}$ Añade la Instrucción de 2006 al RRC — a las reglas generales para la inscripción de los matrimonios celebrados en el extranjero contenidas en los arts. 256 y 257 RRC — que dicho control de legalidad conforme a la ley española es «extenso porque solo así se garantiza que accedan al Registro actos válidos y eficaces» e incluye también «la verificación de la legalidad del acto en cuanto a los requisitos subjetivos del mismo» (Regla VIII) esto es, capacidad y sobre todo consentimiento matrimonial.

${ }^{24}$ Cito literalmente la Instrucción DGRN de 31 de enero de 2006, sobre matrimonios de complacencia, $B O E$ de 22 de marzo de 2006, cfr. Regla VIII. Se reproduce en términos idénticos en la jurisprudencia reciente de la DGRN: así p. ej., RDGRN $\left(47 .{ }^{a}\right.$ y $\left.48^{\circ}\right)$ de 4 de diciembre, (1. $\left.{ }^{a}\right)$ de 18 de diciembre, todas de 2015.

25 Adicionalmente, como todo documento público extranjero debe cumplir las exigencias formales de los arts. 323 y 144 LEC en particular lo relativo a la legalización y traducción para ser presentados. Hay excepciones en el Reglamento UE 22010/2003 para las resoluciones sobre divorcio (art. 52); también con alcance más general debe tenerse en cuenta el Convenio CIEC núm. 17 sobre dispensa de legalización de ciertos documentos relativos al estado civil.

${ }^{26}$ Así parecía cuando se implantó el sistema matrimonial post-constitucional, desde el entendimiento de la estrecha vinculación fondo-forma en el matrimonio, debiéndose admitir aquellos medios de prueba previstos por el ordenamiento extranjero rector de la forma (cfr. GonzÁLEz CAMPOS, J. D., op. cit., nota 5, p. 311). 
del país de celebración (art. 256.3 RRC) y las “declaraciones complementarias oportunas" ${ }^{27}$.

16. En primer término, un documento como medio de prueba de la validez del matrimonio celebrado ante autoridad extranjera. El matrimonio se presume válido pero es preciso acreditarlo ${ }^{28}$. Nótese que el art. 256.3 RRC no especifica el tipo de documento; simplemente se refiere al «expedido por autoridad o funcionario del país de celebración». Esta disposición no puede interpretarse aisladamente sino en el contexto de la legislación registral, y en particular, la que establece qué títulos tienen acceso al Registro Civil ${ }^{29}$. Así pues, sirven como títulos tanto las certificaciones de matrimonio expedidas por autoridades locales intervinientes en la celebración como las certificaciones sobre inscripciones procedentes de registros extranjeros ${ }^{30}$. Estas últimas deben presentar una garantía adicional y es la equivalencia funcional para que sean tratadas como títulos análogos a los nuestros. La DGRN ha exigido que procedieran de un registro regular y auténtico que ofrezca garantías análogas a las exigidas para la inscripción en un Registro español ${ }^{31}$. Cabe así que la inscripción pueda promoverse:

1. ${ }^{\circ} \quad$ Adjuntando la certificación del matrimonio expedido por la autoridad extranjera (art. 256.3 RRC, art. 62.2 CC, art. 59.2 LRC 2011) y el certificado de capacidad matrimonial que haya sido extendido por la autoridad española (ex art. 252 RRC 1986) si lo exigiera la ley del país de celebración, cuando el matrimonio haya sido contraído ante autoridad local extranjera y aquella lo exija (art. 65.2 CC). Debieran ser títulos válidos: a) La certificación expedida por la autoridad (judicial o no) interviniente en la celebración del matrimonio será título de acceso al Registro Civil. Solución facilitadora en la medida en que supone un reconocimiento procesal que evita efectuar el control de la ley aplicada por la autoridad judicial extranjera; b) la certificación registral extranjera. Es más, lo más frecuente es la presentación de dicho documento en el entendimiento de que muchos ordenamientos exigen la inscripción de todos

27 Instrucción DGRN de 31 de enero de 2006.

28 Cfr. Arenas García, R., op. cit., nota 4, p. 233.

${ }_{29}$ Conforme al art. 81 RRC: «El documento auténtico, sea original o testimonio, sea judicial, administrativo o notarial, es título para inscribir el hecho de que da fe. También lo es el documento auténtico extranjero, con fuerza en España con arreglo a las leyes o a los Tratados internacionales», disposición que se reproduce idéntica en el art. 27 LRC.

30 En contra Orejudo PRIETo De Los Mozos, P., op. cit., nota 11, pp. 229 y 231, quien sostiene que dada la ausencia de garantías que concurren en los certificados que emiten las autoridades ante las que se presta el consentimiento «los únicos documentos extranjeros que han de considerarse títulos para la inscripción son las certificaciones registrales; el resto de los documentos han de ser oportunamente valorados en el expediente del que formen parte»; asimismo RoDRíGUEZ GAYÁN, E., Derecho registral civil internacional, 1995, p. 187. Pero ¿qué ocurre si, por ejemplo, el país de celebración no tiene Registro Civil o funciona con carencias muy evidentes? En rigor el art. 257 RRC está previsto precisamente para la ausencia o insuficiencia de título.

31 Véanse RRDGRN de 31 de marzo de 1989, 14 de diciembre de 1990, 21 de enero y 21 y 22 de marzo de 1991, en las que los interesados habían celebrado matrimonio en Marruecos y se denegaba la inscripción al no ser de registros regulares y auténticos (p. ej., procedentes del Tribunal del Cadi notario de Nador o testimonios notariales) (cfr. Rodríguez GAYÁN, E., «Nota», REDI, 1991, núm. 2, pp. 526-530). 
los matrimonios celebrados en su territorio ${ }^{32}$, y c) no es título válido el Libro de familia, pues no es más que un documento administrativo en extracto ${ }^{33}$.

2. ${ }^{\circ} \quad$ Además del documento, el encargado del Registro debe acudir a las «declaraciones complementarias oportunas» (art. 256 in fine RRC 1986). En la práctica se ha interpretado como referido a la audiencia reservada a que se refiere el art. 246 RRC, particularmente desde la Instrucción DGRN de 2006 sobre matrimonios simulados. Es en ese marco en el que se desarrolla el control de validez.

\subsubsection{Inscripciones que requieren la formación de expediente (art. 257 RRC)}

17. Para supuestos distintos de los previstos en el art. 256.3 RRC, en particular, en ausencia de título documental suficiente — como señala la DGRNla inscripción requiere la formación de un expediente cada vez que no pueda acreditarse documentalmente «la celebración en forma del matrimonio y la inexistencia de impedimentos» (art. 257 RRC) ${ }^{34}$. Estos dos extremos son los que deberán quedar acreditados: $1^{\circ}$ ) La «celebración en forma» requerirá una certificación expedida por autoridad extranjera competente. $2 .^{\circ}$ ) La «inexistencia de impedimentos» tiene que ver con el control de la capacidad.

1. ${ }^{\circ}$ En teoría se trata este de un expediente que debe practicarse como título supletorio en los casos en los que haya duda acerca de la realidad del hecho o su legalidad, para la debida comprobación de esos extremos. Es, por ejemplo, el cauce previsto para los matrimonios celebrados en las formas evangélica, hebraica e islámica, según las Leyes 24/1992 y 25/1992 dado que los acuerdos con estas entidades religiosas ciñen su ámbito de actuación al territorio español ${ }^{35}$. Queda sujeto a las reglas generales de los expedientes ${ }^{36}$. El encargado del Registro debe comprobar, por una parte, la celebración en forma del matrimonio: en fecha, lugar y hora y haciendo constar la identidad de los contrayentes. A ese fin deben aceptarse todas las pruebas documentales que sirvan de medio de prueba en el país de celebración. Tienen que aparecer los datos esenciales o, de lo contrario

32 La DGRN tuvo que aclarar que debe tratarse de certificaciones de un registro local (cfr. OREJUDO PRIETO DE los Mozos, P., op. cit., nota 11, p. 229 y nota 979).

33 La LRC añade una previsión que puede facilitar la inscripción: a través de certificación registral extranjera cuando esta solo acredite el contenido de una resolución judicial. En tal caso el título de inscripción será la resolución judicial por tanto sujeta al régimen del art. 96 LRC que difiere en algunas condiciones.

34 OREJUdo DE los Mozos, P., op. cit., nota 11, p. 231, sostiene que la falta de certificación registral determina la tramitación de la inscripción por expediente conforme a lo dispuesto por los arts. 85 y 257 RRC.

35 Cfr. Garau Juaneda, L., "Matrimonio de españoles en el extranjero», en VVAA, Los 25 temas más frecuentes en la vida práctica del Derecho de familia, 2011, pp. 210-217, esp. pp. 213-214; en contra, BlázQuez Rodríguez, I., "La celebración del matrimonio con elemento extranjero. El caso de los ciudadanos marroquíes», en Moya Escudero, M. (dir.), Familia y sucesiones en las relaciones hispanomarroquíes, Valencia, Tirant lo Blanch, 2015, pp. 71-98, esp. p. 95.

36 Cfr. Luces GIL, F., op. cit., p. 241. 
se procederá a la denegación de la inscripción. Puede ocurrir que el documento extranjero tenga por marido y mujer a los interesados, pero falten otros elementos esenciales, incluso tratándose de certificaciones registrales extranjeras. Excepcionalmente se han admitido si se acompañaban de una resolución judicial confirmatoria ${ }^{37}$.

2. ${ }^{\circ}$ En segundo término, el encargado del Registro deberá asegurarse de la «inexistencia de impedimentos», de modo que debe proceder a las «audiencias legalmente exigidas» (art. 261 RRC).

18. Siendo este uno de los dos procedimientos positivizados en la práctica actual, la inscripción por la formación de expediente no fundamenta la inscripción de los matrimonios celebrados en el extranjero. La exigencia en el marco del art. 256.3 RRC de proceder a las «declaraciones complementarias oportunas» equivale de hecho a la formación del expediente, de modo que este segundo cauce ha derivado a un régimen análogo al expediente previo a la celebración del matrimonio ${ }^{38}$.

19. En el momento actual acudir al expediente resulta perfectamente prescindible para la DGRN, como afirma en su doctrina:

«De estos hechos, es una deducción razonable y en modo alguno arbitraria entender que el matrimonio es nulo por simulación. Así lo ha estimado el encargado del Registro consular, quien por su inmediación a los hechos es el que más fácilmente puede apreciarlos y formar su convicción respecto de ellos. Esta conclusión, obtenida en momentos cronológicamente más próximos a la celebración del matrimonio, no quedaría desvirtuada por un expediente posterior, el del art. 257 del RRC, del cual debe prescindirse por razones de economía procesal (cfr. art. $354 R R C$ ), si es que se estima que, además de la vía judicial, quedaría abierto este camino ante la denegación adoptada en la calificación efectuada por la vía del art. 256 del Reglamento ${ }^{39}$.

20. Es el último eslabón en una evolución siempre orientada hacia un refuerzo de los controles ${ }^{40}$. Pone de manifiesto una interpretación que contrasta con la sostenida en un pasado no tan lejano, cuando la DGRN se mostraba más flexible y se dejaba abierta la doble vía de inscripción sin o con expediente. Sirva como muestra una Resolución de 27 de octubre de 1992, en cuyo apartado III establecía:

«Cualquier español puede contraer matrimonio en el extranjero "con arreglo a la forma establecida por la ley del lugar de celebración", pero, aunque la forma sea

37 STS Sala de lo Contencioso de 20 de julio de 2016, sobre reconocimiento de sentencia extranjera procedente de Islamabad. Aunque el problema se plantea en el marco de un procedimiento de reagrupación familiar, no era claro que el matrimonio estuviera inscrito, por lo que la autoridad consular exige homologación judicial de la inscripción registral aportada.

38 Cfr. Peña y Bernaldo de Quirós, M., Derecho de Familia, Madrid, Universidad Complutense, Secc. Publicaciones, 1989, p. 76

${ }^{39}$ Cfr. RDGRN $\left(47 .^{\mathrm{a}}\right)$ de 4 de diciembre de 2015 , idéntica a la $48 .^{\mathrm{a}}$ y $51 .^{\mathrm{a}}$, del mismo día y $11\left(1 .^{\mathrm{a}}\right)$ de diciembre de 2015 , entre otras muchas.

40 Originariamente la inscripción de las certificaciones expedidas por autoridades extranjeras se hacía por transcripción literal, sin calificación; el RRC en su reforma de 1986, introdujo el control de conformidad con la legalidad a través del cauce de las declaraciones complementarias (art. 256.3 RRC) o de la instrucción del expediente (art. 257 RRC). 
válida, es necesario, para poder practicar la inscripción, comprobar que han concurrido los requisitos de fondo exigidos para la validez del enlace, bien se haga esta comprobación mediante la calificación de la "certificación expedida por autoridad o funcionario del país de celebración" (art. 256.3 RRC) y en las condiciones establecidas por este precepto reglamentario, bien se realice tal comprobación, en ausencia de título documental suficiente, a través del expediente previsto por el art. $257 R R C »$.

21. La DGRN tal vez actúa condicionada por el temor al fraude. Por vía de consecuencia se cierra el paso a los interesados a una segunda oportunidad para subsanar errores o aportar nuevas pruebas documentales. Una interpretación desproporcionada en ciertos supuestos: por ejemplo, en los casos de matrimonios contraídos ante autoridad extranjera que exigen el certificado de capacidad matrimonial a los extranjeros, cuando la propia autoridad extranjera pasa por alto una exigencia de $s u$ ordenamiento. Queda expedita, eso sí, la vía judicial, seguramente impracticable en buen número de casos aunque solo sea por la lejanía con el ámbito de la Jurisdicción española.

\subsection{Denegación de la inscripción}

22. La denegación de la inscripción es recurrible ante la DGRN y en su caso en la vía judicial ordinaria ${ }^{41}$. En la práctica se está descartando que la denegación de la inscripción por el encargado del Registro consular -muy frecuente en los supuestos en que hay datos objetivos para calificar como simulado el matrimonio a inscribir - pueda intentarse ulteriormente ante la misma autoridad promoviendo la inscripción en virtud de expediente (art. 257 RRC). Esto es así, a menos que aparezcan hechos nuevos que justifiquen la reiteración por la vía del expediente ${ }^{42}$. No obstante, se ha admitido que el matrimonio de españoles que no haya podido ser debidamente inscrito por no haberse acreditado la libertad de los contrayentes o la inexistencia de impedimentos pueda ser objeto de anotación ${ }^{43}$. En los supuestos de matrimonios simulados o de conveniencia, debe el encargado del Registro consular comunicar de forma directa e inmediata al Registro Civil Central ${ }^{44}$.

41 Denegada la inscripción o si únicamente fue objeto de anotación marginal, los cónyuges pueden: a) intentar acción de nulidad del matrimonio — que también corresponde al fiscal—o $b$ ) intentar obtener una declaración sobre la existencia y validez de la relación matrimonial; si el juez declara la existencia, esa resolución será título bastante para instar de nuevo la inscripción (véase EsPINAR VICENTE, J. M., op. cit., p. 172).

42 Cfr. RDGRN $\left(20{ }^{a}\right)$ de 23 de diciembre de 2015, relativa a la denegación de inscripción por la vía del art. 256.3, en un supuesto de matrimonio por simulación sumamente complejo, procedente del Consulado de Nueva Delhi (India). La DGRN confirma la resolución denegatoria del cónsul estimando que la apreciación del encargado del Registro Consular «no quedaría desvirtuada por un expediente posterior del art. $257 \mathrm{RRC}$ » pero deja abierta la puerta a una ulterior solicitud por la vía del art. 257 al afirmar que: «No obstante lo anterior debe significarse que en los expedientes del registro civil no rige el principio de cosa juzgada, de modo que es posible reiterar un expediente sobre cuestión decidida si hay hechos nuevos que no pudieron ser tenidos en cuenta al dictar la resolución. La vía adecuada para ello es la presentación de una nueva solicitud en el registro civil competente ante el que han de acreditarse esos hechos nuevos».

43 Véase Adroher Biosca, S., op. cit., p. 357.

44 Cfr. Orden Circular MAAEE núm. 435, de 1 de diciembre de 1998 (cfr. París Alonso, J. A., Manual de registro civil para los Registros civiles consulares, Madrid, MAEC, 2008, p. 167). 


\section{PRÁCTICA DE LA DIRECCIÓN GENERAL DE LOS REGISTROS Y DEL NOTARIADO}

23. El dato más sorprendente que se deriva del examen de la práctica reciente es el elevado número de supuestos que llegan a la DGRN desde los Registros consulares así como la variedad en los sustratos fácticos. Se examinan todos los presupuestos de validez del matrimonio contraído ante autoridad extranjera: desde la validez del título a inscribir, la idoneidad de la autoridad interviniente o más ampliamente la capacidad y el consentimiento prestados por los contrayentes. El control es extremo y en la misma línea se inscribe la reforma a introducir por la LRC 2011 que, sin haber entrado en vigor, ya ha sido modificada sustancialmente en materia de inscripción del matrimonio por Ley 15/2015, de 2 de julio, de la Jurisdicción Voluntaria ${ }^{45}$. Llama la atención también una deriva «nacionalista» y "proteccionista» que ha tomado la práctica de la DGRN, a la que ya se ha hecho referencia, confirmando las decisiones denegatorias procedentes del Registro Central o de los Registros consulares, con acierto en unos casos y en otros con resultado ciertamente criticable, también por contraste con lo que ha sido una actitud de la DGRN más «abierta» hacia lo exterior que marcó otras épocas. A los fines expositivos el examen de la práctica se efectúa según que la decisión de las resoluciones retenidas se sustente sobre la forma o sobre el fondo de la celebración del matrimonio celebrado ante autoridad extranjera.

\subsection{Control sobre la forma de celebración}

24. El control sobre la forma de celebración del matrimonio en el extranjero tiene una trascendencia menor en cuanto al número de supuestos de denegación. La denegación se sustenta en la falta de idoneidad de los títulos presentados como medio de prueba así como en el rechazo de determinadas formas de celebración por el tipo de autoridad-no autoridad interviniente, en combinación con sospecha de fraude.

45 Si bien tampoco se especifica qué tipo de documento — si acta de celebración o certificación expedida por la autoridad o certificación registral— (conforme al art. 59.2 LRC 2011 relativo a la inscripción del matrimonio «el matrimonio celebrado ante autoridad extranjera accederá al registro civil español mediante la inscripción de la certificación correspondiente, siempre que tenga eficacia con arreglo a lo previsto en la presente ley»); no obstante, cabe detectar un refuerzo general del control de la legalidad en el art. 58.10 LRC 2011, de modo que si el matrimonio se hubiera celebrado sin haberse tramitado el correspondiente expediente previo el legislador impone al encargado del Registro la obligación de tramitar el expediente para comprobar «si concurren los requisitos legales» para su validez. Así el art. 58.10 «antes de realizar las actuaciones que procedan para su inscripción, deberá comprobar si concurren los requisitos legales para su validez, mediante la tramitación del acta o expediente al que se refiere este artículo». Y el párr. 5 referido al expediente previo impone al encargado del Registro Civil, además de proceder a la audiencia por separado, la posibilidad de «solicitar los informes y practicar las diligencias pertinentes [...] para acreditar el estado, capacidad o domicilio de los contrayentes o cualesquiera otros extremos necesarios para apreciar la validez de su consentimiento y la veracidad del matrimonio». 


\subsubsection{Falta de idoneidad del título}

25. El sistema matrimonial español parte, como ya se ha indicado, de una presunción de validez del matrimonio celebrado en el extranjero. Esa apariencia debe sustentarse sobre un documento de prueba por el que pueda contrastarse la existencia de un matrimonio válido ${ }^{46}$. El acceso al Registro Civil presupone que se acreditará debidamente la celebración en forma del matrimonio, bien sea por documento emitido por la autoridad extranjera de celebración, bien por certificación registral extranjera. Dicha exigencia excluye como es obvio los llamados matrimonios informales o solo consensu, así como aquellos supuestos en que la documentación aportada no sirva para acreditar la celebración.

26. Excepcionalmente, y en una práctica ya lejana en el tiempo, la DGRN se mostró favorable a la inscripción, revocando la calificación del Registro Civil Central, en un supuesto en que la inscripción se había denegado por falta de idoneidad del título. El Registro Central estimó que el documento que acompañaba a la solicitud no constituía un "certificado de matrimonio" sino un «acta notarial de manifestaciones». Pues bien, en una muestra de apertura la DGRN entendió que «si no hay propiamente autorizante del matrimonio por la ley china y si esta no exige la intervención de testigos, no hay motivo alguno para exigir el cumplimiento de requisitos no exigidos por la legislación competente y aplicar en este punto la ley española» ${ }^{47}$. Esta solución hoy es casi impensable.

27. No sirven las certificaciones registrales expedidas por autoridades de la República Árabe Saharaui, al no ser considerados por la DGRN como registros auténticos ${ }^{48}$. Se sigue la línea marcada las RRDGRN de 31 de marzo de 1989, 14 de diciembre de 1990, 21 de enero y 21 y 22 de marzo de 1991, en las que los interesados habían celebrado matrimonio en Marruecos y se denegaba la inscripción al no aportar certificaciones de registros regulares y auténticos (p. ej., procedentes del Tribunal del Cadi notario de Nador o testimonios notariales) ${ }^{49}$. La inadmisión del documento extranjero provoca la denegación de las inscripciones en los supuestos que dan lugar a la RDGRN (7. $\left.{ }^{a}\right)$ de 10 de julio de 2015, en el que los interesados español y mauritana, aportan un «juicio confirmatorio de matrimonio» declarado por un tribunal local; o en la $\left(2 .^{a}\right)$ de 30 de diciembre de 2015 , en la que el promotor aporta «acta inextensa de matrimonio local», impidiéndose tanto la inscripción como la anotación preventiva ${ }^{50}$.

28. Tampoco serán inscribibles, y con razón, al no considerarse suficientemente probada la celebración del acto, por documento marroquí en el que sim-

46 Cfr. Arenas García, R., op. cit., nota 4, p. 234.

47 RDGRN (1..$^{\text {a) }}$ de 2 de enero de 1998, BIMJ, 1998, núm. 1.826, p. 76.

48 Véanse RRDGRN de 29 de marzo y 4 de junio de 2007; lo cual conecta con la falta de reconocimiento de la República Árabe Saharaui por parte del Estado español.

49 Cfr. Rodríguez GaYÁn, E., op. cit., nota 30, pp. 526-530.

50 Debe destacarse que algunos de los supuestos emergen entreverados por la insuficiencia en la documentación presentada con el hecho de que en la audiencia separada el encargado del Registro Consular llega a la convicción de hallarse ante matrimonios simulados. Este segundo elemento tiene mucho más peso en la decisión de denegar la inscripción. 
plemente consta que los contrayentes se casaron, pero sin concretar hora, lugar o autoridad ${ }^{51}$. Ni es título suficiente el «certificado local expedido por la alcaldesa de la comuna» respecto de un matrimonio celebrado en el Congo, supuesto este en el que sí se echa en falta la "certificación del Registro extranjero» ${ }^{52}$. O los «matrimonios por teléfono» pues falta la «fehaciencia del consentimiento expresado por vía telefónica [...] que no podrían inscribirse mediante transcripción literal de la certificación del registro civil paquistaní, requiriendo la tramitación del expediente del art. 257 RRC en el que deberá acreditarse la celebración del matrimonio ${ }^{53}$. También se deniega la inscripción - esta vez por el Registro Civil Central— del «papel blanco» — sin membrete ni distintivo en el que se acreditara la naturaleza de documento oficial- de un matrimonio celebrado a bordo de un velero australiano en el mar territorial de Chile ${ }^{54}$.

\subsubsection{Matrimonios coránicos}

29. Los matrimonios coránicos o celebrados conforme al rito islámico plantean una cuestión que conecta la forma del matrimonio con los requisitos relativos a la capacidad. La ley local extranjera puede - y, por tanto, debe- exigir al contrayente extranjero la presentación de un «certificado de capacidad matrimonial» que no exige, sin embargo, la legislación española. Ello implica que el contrayente español, con carácter previo a la celebración, tiene que someterse al trámite de autorización o expediente previo al matrimonio (art. 252 RRC). Dicho expediente concluye, como es sabido, con la expedición de un certificado de capacidad matrimonial.

30. En algunos casos, si bien queda debidamente acreditada la validez formal del matrimonio por "acta local», la inscripción es impracticable al no haber sido posible acreditar la capacidad, con anterioridad a la celebración del matrimonio, a través del certificado de capacidad matrimonial. Exigido por las autoridades marroquíes a los extranjeros, hay supuestos en los que pese a no haber sido aportado oportunamente, el matrimonio se celebra pues los contrayentes intervienen bajo la apariencia de nacionalidad marroquí siendo uno doble nacional ${ }^{55}$. Promovida la inscripción en Registro español, Central o Consular, queda probado que el certificado no se obtuvo con carácter previo a la celebración. Por lo que la DGRN se decanta por rechazar la inscripción, dado que «deberían haber acreditado previamente la capacidad matrimonial

51 RDGRN (2. ${ }^{a}$ ) de 23 de septiembre de 2009 (citando otras cuatro resoluciones anteriores en el mismo sentido). Contrastan con otras en las que se planteaban problemas de forma análogos (p. ej., ausencia de datos como nombres y apellidos o la fecha o la hora, etc.) en las que la DGRN reprochaba el proceder del encargado considerándose que había que hacer una interpretación «flexible y generosa, siempre que quede clara la realidad del hecho y la identidad de los esposos», casi todas del año 1989 procedentes de Marruecos (pueden consultarse en AdroHer Biosca, S., Forma del matrimonio y Derecho internacional privado, Barcelona, Bosch, 1993, pp. 349 y ss.).

52 Cfr. RDGRN (5..) de 20 de abril de 2010.

53 Cfr. RDGRN de 24 de septiembre de 2007 (cfr. París Alonso, J. A., op. cit. nota 44, p. 169).

54 RDGRN (5. $\left.{ }^{a}\right)$ de 7 de diciembre de 2009.

55 Un español originariamente marroquí, residente en España, será marroquí a los ojos de las autoridades de aquel país y español desde la perspectiva del ordenamiento español (ex art. 9 CC). 
mediante certificación expedida por el Registro Civil correspondiente» ${ }^{56}$, «no cabe reconocer como título inscribible la mera certificación de matrimonio de la autoridad extranjera» ${ }^{57}$.

31. Técnicamente al hilo de estos supuestos se ha destacado la existencia de una antinomia entre los arts. 256.3 y 257 RRC, dado que el acceso al Registro por el art. 256.3 RRC impide tramitar el expediente en el que deberían ser aceptados todos los medios de prueba, incluyendo los que habilite el ordenamiento extranjero conforme al que se celebró el matrimonio ${ }^{58}$. La DGRN mantiene conducir estos supuestos por el cauce del art. 256.3 RRC, que debe completarse con la aportación de la certificación de capacidad a obtener con carácter previo a la celebración, conforme al art. 252 RRC — calificando dicha norma como material para los supuestos internacionales- ${ }^{59}$. La no aportación en el momento de la celebración del matrimonio ha provocado la denegación. Bien es cierto que, por ejemplo, tanto en el caso que da lugar a la Resolución de 4 de enero de 2007 al igual que en otros, confluyen la ausencia de certificado de capacidad con la sospecha fundada en el encargado del Registro Civil Central de hallarse ante un matrimonio celebrado persiguiendo fines distintos de los propios de esta institución ${ }^{60}$.

32. La denegación de la inscripción, a nuestro modo de ver, es tanto más injusta tratándose de contrayentes dobles nacionales españoles-marroquíes que afirman ignorar el carácter preceptivo del certificado de capacidad matrimonial en el Derecho español, cuya presentación tampoco les fue exigida por las autoridades marroquíes al celebrarse bajo la apariencia de nacionalidad común marroquí. Pero lo más destacable de esta orientación no es tanto la desactivación de la eficacia del documento extranjero como título válido para practicar la inscripción, pese a lo establecido por el art. $256.3 \mathrm{RRC}$, como un proceder que supone en cierto modo una injerencia en la actuación de la autoridad extranjera competente en la celebración del matrimonio ${ }^{61}$. Por no mencionar la situación de inseguridad o incertidumbre jurídica para los interesados acerca de la validez del matrimonio ${ }^{62,63}$. Una práctica, en suma,

56 Cfr. RRDGRN (29. $\left.{ }^{a}\right)$ de 10 de mayo de 2012 o (9. $\left.{ }^{a}\right)$ de 19 de mayo de 2009, entre otras.

57 Cfr. RRDGRN (1. $\left.{ }^{a}\right)$ de 1 de julio de 2009, $\left(2 .^{a}\right)$ de 28 de abril de $2010,\left(2 .^{a}\right)$ de 3 de julio de 2015, $\left(61 .^{a}\right)$ de 10 de julio de 2015, entre otras muchas recaídas desde el año 2009.

58 OREJUdo PRIETO DE los Mozos, P., «Inscripción de matrimonios coránicos celebrados en Marruecos, matrimonios coránicos consulares y matrimonios celebrados en el Sáhara occidental», AEDIPr, 2007, p. 1194 ( citando a su vez a GonzÁlez CAMPos, J. D., op. cit., nota 5, p. 188).

59 Cfr. RDGRN de 4 de enero de 2007 (apdo. IV).

60 Véanse RRDGRN de 4 de enero y 20 de marzo de 2007 o la (39. a) de 11 de diciembre de 2015.

61 Técnicamente se justifica a través de una artificiosa caracterización del art. 252 RRC como «norma material de extensión inversa o ad intra», que aparece en otras Resoluciones.

62 Una solución paralela a la que ha dictado el TC acerca de los matrimonios contraídos en forma islámica, sin certificado de capacidad matrimonial y no inscritos, en su controvertida doctrina. En efecto, al afirmar en STC 194/2014, de 1 de diciembre, que «la certificación de la capacidad matrimonial sirve para acreditar la concurrencia de los requisitos de fondo de la validez del matrimonio, por lo que en ausencia de la misma no puede hablarse de un matrimonio existente para la legislación del Estado", está dejando en un limbo jurídico tales supuestos, por ejemplo, como era el caso, a efectos de pensión de viudedad.

(Véase nota 63 en página siguiente) 
del todo ajena a la finalidad primordial del DIPr., orientado a asegurar la continuidad de las relaciones privadas de los particulares ${ }^{64}$.

33. La evolución que ha experimentado el tratamiento de este tipo de matrimonial no puede ser más radical en un lapso de más de diez años. Compárese esta doctrina con la vertida en la RDGRN de 23 de febrero de 1989, en la que se afirmaba que

«un matrimonio coránico es inscribible por transcripción en un Registro Civil Consular o en el Registro Civil Central, con la simple certificación expedida por la autoridad religiosa (art. 256.3 RRC) y las declaraciones complementarias oportunas» ${ }^{65}$.

34. El cambio es radical, al compás tal vez de las circunstancias derivadas de nuestra política inmigratoria.

\subsubsection{Matrimonios consuetudinarios}

35. Con esta denominación se comprenden prácticas diversas, generalmente procedentes de países africanos (Ghana o Guinea Ecuatorial). En realidad los llamados matrimonios consuetudinarios aunque la DGRN rechace la inscripción desde una caracterización que atiende más a la forma — «esa forma de matrimonio choca frontalmente con el sistema jurídico matrimonial instituido en nuestro país»- ${ }^{66}$, realmente resultan inadmisibles por fallos en cuanto a los requisitos de fondo. En los casos procedentes de Guinea Ecuatorial, a través de la información facilitada por el Consulado General de España en Bata, se trata de instituciones matrimoniales que permiten la poligamia, la celebración por menores de doce años e incluso la entrega de una dote por la mujer. Al margen de que el promotor aporte certificado literal del acta de matrimonio consuetudinario donde se acredita que «el matrimonio existe», la inscripción resulta impracticable al apreciarse vulneración del orden público español por infracción de derechos fundamentales ${ }^{67}$. En estos supuestos está justificada la denegación de la inscripción, al ser el modelo de matrimonio por el que se vinculan los contrayentes lo que justamente se estima contrario a los valores del ordenamiento español.

${ }^{63}$ A menos que se entienda que la ausencia de certificado de capacidad matrimonial no conlleva per se la nulidad del matrimonio sino que sería subsanable ex art. 65 CC y la declaración VI de la Instrucción DGRN de 10 de febrero de 1991 (véase en este sentido BLÁzQuEZ RodRíGUEZ, I., «Matrimonio celebrado por el rito islámico, certificado de capacidad matrimonial y Derecho internacional privado", Cuadernos de Derecho Transnacional, octubre de 2015, pp. 382-399, esp. p. 392).

${ }^{64}$ Véase para un análisis crítico, CARrascosa GonZÁLEZ, J., "Matrimonio y parejas de hecho», en Calvo Caravaca, A. L. y Carrascosa González, J., Derecho internacional privado, Granada, Comares, 2014, p. 11; Orejudo PRIETO DE los Mozos, P. , op. cit. nota 58; id., "Tratamiento registral de los matrimonio de complacencia. Lectura crítica de la Instrucción de 31 de enero de 2006», La Ley, núm. 4/2006, pp. 1547-1559.

65 Véase París Alonso, J. A., op. cit., nota 44, p. 181.

66 Cfr. RRDGRN (25. $\left.{ }^{\mathrm{a}}\right)$ de 23 de enero de 2015, (184. $\left.{ }^{\mathrm{a}}\right)$ de 28 de agosto de 2015.

67 P. ej., RRDGRN (25. $\left.{ }^{a}\right)$ de 23 de enero 2015, $\left(184 .^{a}\right)$ de 28 de agosto de 2015, (3..$\left.^{\text {a }}\right)$ de 1 de junio de 2015, entre otras. 


\subsubsection{Matrimonio en forma canónica}

36. El control se proyecta incluso si la celebración por autoridad religiosa canónica ha sido acreditada mediante certificación expedida por la Iglesia Católica siendo uno de los contrayentes español ${ }^{68}$. A los matrimonios contraídos en el extranjero en forma canónica se aplica en rigor el régimen general al estar comprendidos dentro del supuesto del art. $65 \mathrm{CC}^{69}$ : el título para la inscripción se conforma con la certificación (eclesiástica) expedida por la autoridad extranjera y las «declaraciones complementarias» de los contrayentes, para contrastar que el matrimonio que se pretende inscribir reúne todos los requisitos legales. La transcripción de la inscripción en registro extranjero no exime al encargado del Registro de proceder a «las declaraciones complementarias oportunas», en cuya tramitación llega a la convicción de ausencia de consentimiento matrimonial ${ }^{70}$.

\subsection{Control sobre la capacidad nupcial}

37. El control de los requisitos de fondo para determinar la validez del matrimonio pivota mayoritariamente en un rechazo de la ley personal del cónyuge extranjero en todos los supuestos en que conforme a Derecho español el matrimonio es potencialmente nulo (ex art. $73 \mathrm{CC}$ ). En particular, cuando esa hipotética ley no sanciona con nulidad el matrimonio contraído por españoles menores de edad, la subsistencia del vínculo matrimonial anterior o las múltiples formas de poligamia son supuestos habituales de no reconocimiento.

\subsubsection{Menor de edad}

38. Se deniega la inscripción cuando el matrimonio celebrado en el extranjero involucra a una menor de edad de nacionalidad española ${ }^{71}$. Aunque

${ }^{68}$ En contraste, los matrimonios celebrados en forma canónica en España, resultan inscribibles con la mera presentación del acta matrimonial extendida por la autoridad eclesiástica.

${ }^{69}$ Entre las primeras RRDGRN la de 19 de abril de 2008, $\left(3 .^{\mathrm{a}}\right)$ de 10 de mayo de 2008, (2. $\left.{ }^{\mathrm{a}}\right)$ de 29 de septiembre de 2009, $\left(1 .^{\mathrm{a}}\right)$ de 14 de octubre de 2009, o (5. $\left.{ }^{\mathrm{a}}\right)$ de 15 de diciembre de 2009. Más recientes, (14. $\left.{ }^{a}\right)$ de 13 de marzo de 2012, (36. $\left.{ }^{a}\right)$ de 22 de junio de 2012.

${ }^{70} \mathrm{El}$ art. $63 \mathrm{CC}$ se refiere a los matrimonios en forma religiosa celebrado en España, para los que basta la presentación de la certificación expedida por la autoridad eclesiástica; en una época se sostuvo que el reconocimiento del matrimonio contraído en forma canónica en el extranjero al ser idéntico al matrimonio en forma civil, dado que el Acuerdo con la Santa Sede no introdujo límite territorial y la presencia de la Iglesia católica es mundial (véase RDGRN de 2 de noviembre de 1981; criticada por GonzÁLEZ CAmpos, J. D., al entender que los Acuerdos solo regulan los efectos civiles de los matrimonios canónicos celebrados en España estando los celebrados en el extranjero comprendidos dentro del supuesto del art. $65 \mathrm{CC}$ y por tanto sujetos al régimen general de reconocimiento y, en particular al art. 73 LRC que exige la formación de expediente (cfr. "Nota», REDI, núm. 2, 1982, p. 521). La inscripción de los matrimonios celebrados en el extranjero en las formas previstas por las confesiones religiosas con las que España tiene suscritos acuerdos por Leyes 24, 25 y 26/1992, de 10 de noviembre (evangélica, israelita e islámica) no permite la equiparación dado que las autoridades intervinientes son las previstas por el Registro de Confesiones religiosas (cfr. ARENAS GARCÍA, R., op. cit., nota 4, p. 228; adde. supra nota 35).

71 P. ej., RRDGRN $\left(2 .^{a}\right)$ de 25 de enero de 2003, $\left(4 .^{a}\right)$ de 21 de noviembre de 2008, $\left(3 .^{a}\right)$ de 3 de febrero de 2009 
se haya celebrado matrimonio válido conforme a la lex loci, con catorce años, dado que conforme a Derecho español no pueden contraer matrimonio los menores de edad no emancipados (art. $46 \mathrm{CC}$ ), el matrimonio se ha declarado en principio, nulo, y no inscribible en el Registro Civil español «a salvo la posibilidad de que la interesada solicite la dispensa ulterior de edad, que compete, en primera instancia, al juez encargado del Registro Civil del domicilio (arts. 48 y 365 RRC)» ${ }^{72}$.

\subsubsection{Subsistencia de vínculo matrimonial anterior}

39. Como es sabido el impedimento de ligamen determina la incapacidad para contraer matrimonio por persona casada so pena de nulidad (art. 46.2 CC). Explica que, aunque sean conformes a la ley local, no puedan acceder al Registro Civil español los matrimonios en los que subsiste vínculo matrimonial anterior y, con mayor razón, si el matrimonio anterior está inscrito en el Registro español. Tratándose de españoles, conforme a una práctica reiterada de la DGRN, lo correcto es solicitar el exequátur del divorcio y obtenido este, instar la inscripción del segundo matrimonio. El auto por el que se reconoce el divorcio permite la remoción del impedimento de ligamen ${ }^{73}$.

40. En el caso que dio lugar a la RDGRN (20. $\left.{ }^{2}\right)$ de 3 de julio de 2015, la interesada de nacionalidad española, solicitaba al Registro Civil Central la inscripción de su segundo matrimonio con norteamericano celebrado en Estados Unidos. Solicitud que fue denegada una vez comprobado que la interesada contrajo matrimonio en Estados Unidos en 2001 cuando aún estaba casada, dado que el divorcio de su primer matrimonio lo obtuvo con posterioridad a la celebración del segundo. El segundo matrimonio adolece pues de causa de nulidad. El sustrato fáctico es similar en otros casos, con la particularidad a veces, de que el matrimonio (segundo) que se pretende inscribir ha sido celebrado en forma coránica ${ }^{74}$. La DGRN ya concretó que para valorar si el segundo matrimonio fue contraído subsistiendo el vínculo matrimonial anterior, debe tomarse en cuenta la fecha en que se dictó la sentencia de divorcio o de disolución del vínculo y no la fecha posterior en la que obtuvo el exequátur ${ }^{75}$. La solución puede ser adecuada por la necesidad de coherencia interna del Registro pero no satisfactoria para el promotor.

72 RDGRN (45. $\left.{ }^{\mathrm{a}}\right)$ de 23 de agosto de 2012.

73 Véanse RRDGRN de 3 y 11 de junio de 1996 (siendo entonces todavía competente el TS). En Resolución (3. ${ }^{\text {a }}$ de 1 de junio de 2009, se indica que es necesario el previo reconocimiento de la sentencia de divorcio, ante el Juzgado de Primera Instancia competente por razón del domicilio. En realidad tanto la Ley de Cooperación Jurídica internacional en Materia civil de 2015 (art. 59) como la LRC 2011, cuando esté en vigor (art. 96), permiten el llamado reconocimiento incidental de suerte que la modificación de los datos registrales mediante aportación de la sentencia extranjera puede activarse ante el propio encargado del Registro.

${ }^{74}$ Véase RDGRN (41. $\left.{ }^{\mathrm{a}}\right)$ de 11 de diciembre de 2015; igualmente procedente del Registro Consular de Gambia, Resolución (49. ${ }^{\text {a) }}$ de 4 de diciembre de 2015.

75 RDGRN (4. $\left.{ }^{a}\right)$ de 21 de mayo de 2003. 


\subsubsection{Poligamia}

41. No siempre es la subsistencia de varios vínculos matrimoniales anteriores lo que impide la inscripción de matrimonios poligámicos en sus muy diversas manifestaciones. El mero hecho de la celebración de matrimonio bajo el rito islámico puede ser determinante del rechazo a la inscripción, sustentado sobre la base de la infracción del orden público español.

42. El examen de la práctica reciente revela, de nuevo, un incremento de solicitudes de inscripción planteadas por nacionales españoles nacionalizados pero originarios de países que admiten tales prácticas, incremento que se corresponde con una denegación casi sistemática de la práctica de la inscripción. En la documentación aportada queda acreditada «en el acta de matrimonio la opción por la poligamia» ${ }^{76}$, o la «sumisión sin condición alguna a la Sharía implicando con ello un matrimonio poligámico» ${ }^{77}$. En unos casos la solicitud se dirige al Registro Civil Central y en otros a los Registros Consulares. Es cierto que en algunos casos parece mediar una opción expresa por la poligamia ${ }^{78}$. Pero en otros, la celebración del matrimonio conforme a lo que es el régimen legal en un determinado ordenamiento, no debería llevar a presuponer una voluntad —en todo caso implícita— de los contrayentes por la opción poligámica.

43. Debe recordarse que el orden público (ex art. $12.3 \mathrm{CC}$ ) ha de interpretarse restrictivamente y ser proyectado atendiendo a las circunstancias del caso concreto. Visto así, debe recordarse también, que una cosa es el matrimonio potencialmente poligámico - porque así se conciba en la legislación nacional del o de los contrayentes-y otra el que es realmente poligámico, porque el interesado no acredita la disolución del vínculo o vínculos anteriores.

44. En estos casos, no le falta razón a la DGRN para confirmar la denegación de la inscripción por infracción del orden público ${ }^{79}$. En cuanto a los potencialmente poligámicos, no hace tanto tiempo que la DGRN admitía su validez siempre y cuando se tratara del primer vínculo conyugal de ambos contrayentes $^{80}$. Así, resulta sorprendente la RDRGN (202. ${ }^{a}$ ) de 28 de agosto de 2015, en la que se afirma que «es indiferente que el contrayente esté divorciado de los matrimonios anteriores de manera definitiva de acuerdo con la legislación islámica», tratándose de la inscripción de una española naturalizada y originaria de Bangladesh, cuyo matrimonio se había celebrado bajo la legislación islámica ${ }^{81}$.

76 P. ej., RRDGRN (3. ${ }^{\mathrm{a}}$ y 1 . $^{\mathrm{a}}$ ) de 10 de julio de 2015 (Senegal).

77 P. ej., RRDGRN (6. ${ }^{\mathrm{a}}$ ) de 10 de julio de 2015 (Gambia), (10. ${ }^{\mathrm{a}}$ ) de 31 de julio de 2015 (Gambia); igualmente procedente del Registro Consular de Gambia, Resolución (49. ${ }^{a}$ ) de 4 de diciembre de 2015.

78 Así en RDGRN (32. ${ }^{\text {a) }}$ de 11 de diciembre de 2015.

79 Así, RRDGRN (61. ${ }^{\mathrm{a}}$ ) de 12 de mayo de 2014, o (31. ${ }^{\mathrm{a}}$ ) de 24 de abril de 2014.

80 Así RDGRN de 23 de abril de 1998. En la doctrina se sostuvo que si se trata de un matrimonio potencialmente poligámico en el que el estatuto personal del marido lo es y el de la mujer no, el matrimonio se convierte en monógamo con la adquisición de la nacionalidad española (cfr. GARCía RoDRíGUEZ, I., op. cit., nota 2, p. 280).

81 Véase adde. RDGRN de 20 de octubre de 1998, BIMJ, 1999, núm. 1.850, pp. 2406-2408. 
45. Bien es cierto que la tipología de casos que arroja el matrimonio celebrado en Marruecos es muy variada ${ }^{82}$, dominando los problemas de prueba de la disolución de vínculos anteriores cada vez que uno de los contrayentes ha adquirido con posterioridad la nacionalidad española. Tampoco es fácil tomar en cuenta la especial posición de la mujer para superar el problema de la prueba del repudio en ciertos casos. Con todo, parece que presuponer la naturaleza poligámica del matrimonio celebrado en forma islámica va mucho más allá. Permitir hacer valer a los interesados algún otro medio de prueba o manifestación parece ineludible. La no inscripción puede ser un resultado excesivo en algunos supuestos y llegar a comportar una infracción del derecho fundamental al matrimonio, aunque ello no se traduzca en reclamaciones en vía judicial. Una posibilidad de flexibilización podría articularse dando a los contrayentes el derecho a revocar o renunciar a dicha práctica, por ejemplo, ante fedatario público o ante el encargado del Registro. Tampoco es un procedimiento ajeno a nuestro ordenamiento. Por razones similares se introdujo en materia de reconocimiento de la adopción constituida fuera, para los supuestos en que la ley local de constitución admitía las llamadas adopciones revocables ${ }^{83}$.

\subsection{Control sobre el consentimiento matrimonial}

46. El consentimiento matrimonial es elemento clave para determinar la validez del matrimonio a inscribir. Es inmenso el número de Resoluciones que rechazan la práctica de la inscripción.

\subsubsection{Matrimonios acordados}

47. En la doctrina y en la práctica de algunos países, se diferencian estos de los matrimonios «pactados» o «convenidos» pues aunque la familia concierta el matrimonio, el consentimiento se presta de forma voluntaria, es decir, que la tipología es variada ${ }^{84}$. En todo caso se ha afirmado con buen criterio, que no hay consentimiento libre en matrimonios acordados por españoles convertidos al Islam, "cuando se celebran por la voluntad del padre o tutor y sin consentimiento o contra la voluntad del hijo o hija, aun cuando ello sea conforme con costumbre inmemoriales», y en consecuencia debe denegarse su inscripción ${ }^{85}$. Respecto de estos matrimonios al igual que en los supuestos de contrayentes de menor edad, creo que el dato determinante es la proximidad de las situaciones a reconocer con la esfera del ordenamiento español. La ma-

82 Un buen resumen hasta el año 2000 puede consultarse en GARcía RodRíGUEZ, I., op. cit., nota 2, pp. 284-294.

${ }^{83}$ Es una idea expresada por ORejudo PRIETo DE los Mozos, P., «Nota» a la RDGRN (202.. ) de 28 de agosto de 2015, AEDIPr, 2016, p. 1324.

${ }^{84}$ Cfr. Elvira Benayas, M. J., «Matrimonios forzosos», AEDIPr, t. X, 2010, pp. 707-715.

85 Circular MAEC núm. 218, de 27 de julio de 2005 (cfr. en PARís Alonso, J. A., Manual de registro civil... op. cit., nota 44, p. 170). 
yor proximidad, determinada por la nacionalidad española de uno de los cónyuges es el criterio determinante en la decisión de impedir el reconocimiento.

\subsubsection{Matrimonios simulados}

48. El matrimonio simulado ha sido caracterizado por la ausencia de un verdadero consentimiento matrimonial siendo en la práctica de la DGRN los más numerosos y los que suscitan mayores problemas de prueba. El encargado del Registro debe actuar como en la instrucción del expediente previo ${ }^{86}$. Le corresponde identificar esta situación y asociar las consecuencias pertinentes derivadas de la eventual nulidad, rechazando en su caso la inscripción en el Registro Civil ${ }^{87}$. Es deber del encargado cerciorarse de la inexistencia de impedimentos u otros obstáculos que provoquen la nulidad del matrimonio desde la perspectiva española. Las pruebas están basadas en presunciones, de modo que su admisión requiere: a) que los indicios estén demostrados; b) que se dé una relación causal entre hechos objetivos e indicios ${ }^{88}$ y c) que si existen otras razones que expliquen los indicios, se analicen y expliquen las causas de un eventual rechazo de la inscripción ${ }^{89}$.

49. Por otra parte, el principio de exactitud registral impone al encargado del Registro que podrá inscribir «siempre que no haya dudas acerca la realidad del hecho y de su legalidad conforme a la Ley española ${ }^{90}$. Desde el momento en que exista duda, bien sobre la realidad del hecho, bien sobre la legalidad del matrimonio, cabe la denegación de la inscripción. La práctica se mueve entre dos polos: la denegación o la práctica de la inscripción en función del resultado de los mecanismos de control, en particular, la audiencia reservada con cada uno de los contrayentes. Recuérdese que la Instrucción de 2006 avala finalmente la aplicación de la ley española —en España incluso si ambos contrayentes son extranjeros-.

50. La denegación de la inscripción se sustenta en la certeza acerca de la ausencia de un verdadero consentimiento matrimonial conlleva la denegación de la inscripción en el Registro Civil Consular del que fue válidamente celebrado conforme a la ley local ${ }^{91}$. La argumentación -expresa aunque no siempre- se construye en torno a la idea de infracción del orden público español (ex

86 Cfr. Instrucción DGRN de 31 de enero de 2006, sobre matrimonios de complacencia.

87 Conforme al art. 74 CC la acción no prescribe y la legitimación corresponde a cónyuges, Ministerio Fiscal y cualquier otra persona que tenga un interés directo y legítimo.

${ }_{88}$ P. ej., si se conocieron y trataron por vídeo, es un hecho que levanta sospecha [RDGRN (1.a) de 18 de enero de 2005].

${ }^{89}$ El problema también se proyecta en fase de autorización del matrimonio. En general, se ha sostenido que aun existiendo fundadas sospechas, si los interesados se ratifican en su intención de contraer matrimonio, parece obligada su autorización (véase DomínguEz LozANo, P., «Instrucción de la DGRN de 9 de enero de 1995 sobre expediente previo al matrimonio cuando uno de los contrayentes está domiciliado en el extranjero», REDI, 1995, núm. 1, pp. 317-318, esp. p. 318).

90 Cfr. Díaz Fraile, J. M., op. cit., nota 19; Luces Gil, F., op. cit., nota 18, p. 36.

91 Véanse RRDGRN (6. $\left.{ }^{a}\right)$ de 29 de mayo de 2006, (2. ${ }^{\text {a }}$ ) de 2 de julio de 2009, (29. ${ }^{\text {a) }}$ de 10 de mayo de 2012, o (4. $\left.{ }^{\mathrm{a}}\right)$ de 24 de julio de 2015, entre otras muchas. A idéntica conclusión se llega cuando el matrimonio ha sido celebrado en España [cfr. RDGRN (29. ${ }^{a}$ ) de 10 de mayo de 2012, entre otras muchas]. 
art. $12.3 \mathrm{CC}$ ): deducida la ausencia de consentimiento matrimonial, dado el carácter de requisito esencial del consentimiento para la validez del matrimonio en el extranjero «hay excepción de orden público respecto a ley extranjera que admite la validez del consentimiento matrimonial simulado" ${ }^{92}$. Pero en una gran mayoría de supuestos hay una aplicación directa de la ley española: a partir de unos hechos objetivos, el encargado hace una deducción razonable de que el matrimonio es nulo por simulación denegando la inscripción ${ }^{93,94}$.

51. Cuando la denegación procede de Registros consulares hay un total desplazamiento a los encargados en el extranjero y es frecuente la fórmula por la que la DGRN entiende que «por su inmediación a los hechos más fácilmente puede apreciarlos y formar la convicción respecto de ellos» ${ }^{95}$. Desplaza así sobre los funcionarios diplomáticos y consulares la responsabilidad inicial de decretar una nulidad administrativa del matrimonio que, como veremos, es cuestionable desde distintos ángulos, por más que tales funcionarios ostenten por el Convenio de Viena sobre Relaciones Consulares una función expresa como encargados del Registro Civil.

52. La tendencia señalada coexiste con otra en la que se admite la inscripción. En efecto, la tensión que provoca el hecho de estar en juego el derecho fundamental al matrimonio fundamenta otras Resoluciones en las que el control posterior y a pesar de la sospecha, se concluye que no hay datos determinantes para denegar la inscripción del matrimonio válidamente celebrado conforme a la ley local ${ }^{96}$; o que siendo «posible la falta de intención de contraer matrimonio a los fines propios de dicha institución, lo cierto es que no existen elementos de juicio para afirmarlo con el suficiente grado de certeza», por lo que se ordena la práctica de la inscripción ${ }^{97}$. Una solución justa aunque solo sea porque la DGRN, ante la duda, deja prevalecer el derecho fundamental al matrimonio.

92 P. ej., RDGRN (7.. ${ }^{a}$ ) de 24 de julio de 2015.

93 P. ej., RRDGRN (4. ${ }^{\text {a) }}$ de 2 de enero de 1998, y de 8 de abril de 1998.

94 Un aspecto que no podemos abordar con amplitud es el de la acción del orden público. En rigor en muchas de las resoluciones en las que se impide la inscripción por fallos en la capacidad o el consentimiento, no se suscita el problema de la aplicación de la ley extranjera, dado que los contrayentes no tienen que alegar el Derecho extranjero; luego no se activa la cláusula de orden público como mecanismo de evicción de la ley (personal) extranjera inicialmente competente. Hay simplemente una extensión de ciertas normas imperativas de nuestro sistema matrimonial a supuestos creados en el extranjero. Como hace años denunciara Orejudo Prieto de los Mozos, P., op. cit., nota 11, pp. 8384 , hay un uso indebido y excesivo del orden público: ni se alega ni se consulta la ley extranjera; en realidad lo que se suscita es un problema de prueba, dado que la autoridad registral se enfrenta a la cuestión de reconocer la disolución de un vínculo matrimonial anterior o de que se acredite la capacidad nupcial.

95 Como ya se ha indicado, cada vez es más frecuente que la DGRN cierre el paso a la formación de un posible expediente para proceder a la inscripción (ex art. $257 \mathrm{RRC}$ ) «por razones de economía procesal», dejando abierta únicamente la vía judicial; véase entre otras, RDGRN (1. a) de 5 de abril de 2010.

96 A partir de la RDGRN (2. $\left.{ }^{a}\right)$ de 9 de octubre de 1993, probablemente la primera en la que se revoca la actuación consular de Túnez; asimismo RRDGRN $\left(2 .^{\mathrm{a}}\right)$ de 2 de enero de 1998, de 20 de marzo de 1999, $\left(8 .^{a}\right)$ de 20 de abril de 2010, (4..$\left.^{a}\right)$ de 2 de junio de 2009, (17. $\left.{ }^{a}\right)$ de 10 de febrero de 2012, (33. $\left.{ }^{a}\right)$ de 17 de febrero de 2012 y $\left(22 .^{a}\right)$ de 28 de junio de 2012, entre otras muchas.

97 Cfr. RRDGRN (2. ${ }^{\mathrm{a}}$ ) de 1 de julio de 2009, $\left(36 .{ }^{\mathrm{a}}\right)$ de 22 de junio de 2012, entre otras muchas que cristalizan en idéntica argumentación y resultado. 


\subsubsection{Celebración del matrimonio fuera y posterior nacionalización española de uno de los cónyuges}

53. Una aproximación flexible se percibe también en los supuestos en que el matrimonio fue celebrado entre extranjeros, en el extranjero, y ulteriormente uno de los contrayentes se nacionaliza español. Al promover la inscripción del matrimonio en el Registro Civil español deviene sobrevenidamente competente. En un caso, pese a la sospecha de matrimonio simulado, afirma la encargada que como quiera que «no existen dudas de que el enlace ha cumplido los requisitos de fondo y forma exigidos por la ley extranjera aplicable [...] que habrían sido apreciados favorablemente por la autoridad extranjera competente» procede su inscripción ${ }^{98}$. En cambio, en supuesto fáctico idéntico, del trámite de audiencia reservada se dedujo que «el matrimonio celebrado no ha perseguido los fines propios de la institución» por lo que se impide el reconocimiento y por tanto la inscripción ${ }^{99}$.

54. Dentro de la inmensa variedad de casos en tiempos recientes emergen un número importante de Resoluciones que confirman la actuación del encargado del Registro consular denegando la inscripción de matrimonios válidamente celebrados conforme a la ley local. Una mayoría proceden de República Dominicana y Cuba, contraídos por contrayentes en los que uno es español, originariamente dominicano o cubano, habiendo adquirido la nacionalidad española bien por opción, bien por residencia en España por parte de uno de los contrayentes o incluso acogiéndose a la Ley 52/2007, de 26 de diciembre, de Memoria histórica. Los hechos anteriores al nacionalizado interesan al Registro español. No es posible establecer la razón por la cual un número mayor de supuestos proceden de los Consulados en determinados países (República Dominicana y Cuba, en particular) y no de otros; dato que sin duda tenga que ver con una mayor diligencia de los funcionarios diplomáticos y consulares presentes en estos países.

55. En el trámite de las declaraciones complementarias, determinadas afirmaciones indican al encargado del Registro (consular) la ausencia de consentimiento matrimonial, y por consiguiente, la sospecha de fraude y de la eventual nulidad del matrimonio ${ }^{100}$. Excepcionalmente la duda no es suficiente para denegar la inscripción ${ }^{101}$. En ciertos supuestos se cruzan la sospecha de simulación con matrimonio poligámico. Pero el argumento determinante es la certeza, a partir de los documentos aportados, de la subsistencia del vínculo matrimonial anterior, por quedar acreditada la separación y no el divorcio ${ }^{102}$.

56. Afirmar la (posible) nulidad del matrimonio por simulación del consentimiento es una cuestión compleja, ciertamente, pero criticable desde el

\footnotetext{
98 RRDGRN (4. ${ }^{\mathrm{a}}$ ) de 2 de junio de 2004, $\left(21 .^{\mathrm{a}}\right)$ de 10 de febrero de 2012.

99 RDGRN (1.. $)$ de 27 de abril de 2012.

100 Entre las 25 dictadas en julio de 2015, véanse RRDGRN (1. ${ }^{\mathrm{a}}$ ) de 1 de julio de 2015 (La Habana), $\left(2 .^{a}\right)$ de 1 de julio de 2014 (Rep. Dominicana), (2. $\left.{ }^{a}\right)$ de 24 de julio de 2015 (Guayaquil).

101 P. ej., RDGRN (64. $\left.{ }^{\mathrm{a}}\right)$ de 12 de junio de 2015

102 P. ej., RDGRN (3. ${ }^{a}$ ) de 30 de julio de 2015.
} 
análisis jurídico, que no podemos abordar en toda su amplitud. Utilizar las «declaraciones complementarias oportunas» (ex art. 256 RRC) como vehículo para establecer a partir de ciertos hechos la nulidad del consentimiento, no deja de ser un método desproporcionado de control en sede de reconocimiento ${ }^{103}$. Supone de algún modo desactivar lo actuado por autoridad extranjera. El aspecto más controvertido tiene que ver con una cierta alteración de la función registral de calificación. La calificación registral es un control formal de apariencia de legalidad basada en hechos, no un control sustancial de legalidad basada en intenciones ${ }^{104}$. La eventual simulación del consentimiento no aporta nada a la apariencia de legalidad ${ }^{105}$. Lo que ocurre es que la Instrucción de 2006, convierte el consentimiento en un elemento objetivable, como la capacidad o la forma ${ }^{106}$. No por preservar la legalidad de las situaciones que han de acceder al Registro sino en aras de un control administrativo orientado a impedir la inmigración. Por vía de consecuencia, el encargado del Registro establece la nulidad administrativa del matrimonio ${ }^{107}$. Asume una función judicial que no tiene expresamente atribuida - menos aún los funcionarios diplomáticos y consulares- cual es, la de juzgar sobre la validez del matrimonio tratándose de una materia objeto de las llamadas acciones de Estado. La nulidad solo puede ser declarada judicialmente y únicamente es competente la jurisdicción civil en primera instancia ${ }^{108}$. ¿Alternativas? Que ante la duda, el encargado del Registro consular diera traslado al juez civil competente correspondiente al domicilio en España de uno de los cónyuges. Se objetará, con acierto, que colapsaría juzgados ${ }^{109}$.

103 Dejamos a un lado una cuestión importante en clave de constitucionalidad que ya se ha denunciado y es la relativa a la entrevista reservada de cada uno de los contrayentes en la medida en que por el tipo de preguntas se pueda incurrir en infracción de derechos fundamentales cada vez que se formulen cuestiones sobre creencias religiosas o aspectos relativos a la intimidad de las personas (cfr. Orejudo Prieto de los Mozos, P., op. cit., p. 1160).

104 Cfr. en este sentido SÁnchez LoREnZo, S., op. cit., esp. p. 269.

105 Con toda claridad el TS acaba de establecer, entre otros muchos elementos relativos a los matrimonios simulados, que «la finalidad de los contrayentes, las reservas mentales en el fuero interno [...] no son objeto, fueren o no las propias de asumir un proyecto de vida en común, circunstancia que se pruebe en la inscripción registral» [cfr. STS 1486/2017, de 6 de abril (Sala de lo Penal) FJ 6]. Se da en estos una discrepancia entre la voluntad declarada y la exigida para contraer matrimonio, sin duda; pero es cuando menos dudoso que el consentimiento matrimonial deba prestarse respecto de un contenido cuando a partir de la reforma del Código Civil de 2005, el matrimonio quedó desprovisto de un contenido en deberes al admitirse el divorcio por voluntad de una sola de las partes, sin causa alguna.

106 Además en la doctrina civilista está establecido que el matrimonio civil requiere un consentimiento verdadero de querer contraer matrimonio, pero ello no prejuzga los móviles o la finalidad para la que este consentimiento se presta (cfr. Dítz-PicAzo, L. y Gullón, A., Sistema de Derecho civil, IV, Madrid, 8. ${ }^{\text {e }}$ ed., 2001, p. 80).

107 Expresión que utiliza SALVAdor GutiérRez, S., «Registro civil, inmigración y matrimonio», en Gutiérrez SÁnchez, J. V. (dir.), Registro Civil: Incidencia del fenómeno de la inmigración. Cuadernos de Derecho Judicial IV, 2004, p. 268.

108 Así lo recuerda la STS 1486/2017 cit., FJ 2.

109 Cuando se solicite la inscripción registral del matrimonio (potencialmente nulo) corresponde al encargado del Registro dar traslado al Ministerio Fiscal actuar en consecuencia e instar la acción de nulidad (art. 74 CC). Hay pues, junto al control preventivo, un instrumento de persecución ex post consistente en instar la nulidad del matrimonio a instancia del Ministerio Fiscal (cfr. arts. 73.1 y 74 CC y 247 RRC 1986). 


\subsubsection{Matrimonio por poder (art. $258 \mathrm{RRC}$ )}

57. El matrimonio por poder es en rigor una forma de contraerlo. El encargado del Registro puede ser requerido para inscribir un matrimonio celebrado por poder conforme a la ley y autoridad local. Supuesto tipo sería aquel en que una extranjera contrae matrimonio por poder otorgado en el extranjero con un ciudadano español residente en España. O a la inversa, español que otorga poder para que el acto de celebración del matrimonio tenga lugar en el extranjero.

58. El control previo a la inscripción se proyecta sobre los matrimonios contraídos por poder y conforme a la ley local, con el consiguiente margen de apreciación para el encargado del Registro, con frecuencia el funcionario consular. La DGRN mostró sus dudas en algún caso en que ambos habían actuado a través de representante. Pero se accedió a la inscripción al ser una forma admitida por la ley local y el matrimonio quedo inscrito en el Consulado español en Montevideo ${ }^{110}$.

59. La inscripción se ha denegado cuando otorgado poder por español a otro español para que actuara en su representación en Cuba, resultaba que la otra parte era menor de quince años, lo que unido a otros hechos llevaba al cónsul a la convicción de estar ante matrimonio simulado ${ }^{111}$. También cuando de la documentación aportada quedaba acreditada la presencia de ambos contrayentes en el acto de celebración, dato que inducía a la sospecha de fraude en la autoridad consular ${ }^{112}$. En otros supuestos la denegación se basaba en que pese a haber sido válidamente contraído por poder conforme a la ley local, vistos los hechos y datos relevantes relativos a los contrayentes y a sus circunstancias personales y familiares cabía deducir la ausencia de consentimiento matrimonial. En los correspondientes recursos de las resoluciones consulares, la DGRN ha extendido el control vía audiencia reservada también a este tipo de matrimonios ${ }^{113}$.

\section{CONCLUSIÓN}

60. De la práctica examinada, junto a Resoluciones en las que tiene lugar un control de legalidad riguroso y proporcional a la finalidad del Registro Civil, otras Resoluciones son más cuestionables, bien porque denotan una resistencia a admitir instituciones matrimoniales no coincidentes con el modelo español, que se hace imperativo hacia lo exterior, bien porque parecen mediatizadas por el temor al fraude. Dos son los aspectos más negativos: por

110 RDGRN de 29 de mayo de 1993.

111 RDGRN de 9 de enero de 1996.

112 RDGRN de 2 de octubre de 2007.

113 Es una medida que «debe adoptarse cuando se trata de inscribir en el Registro Consular o en el Central un matrimonio ya celebrado en la forma extranjera permitida por la lex loci» [RRDGRN (2. $\left.{ }^{\mathrm{a}}\right)$ de 2 de enero de 2003, o (6..$\left.^{a}\right)$ de 29 de mayo de 2006]. 
una parte, el cierre de la vía a la inscripción por expediente en los supuestos en los que en la base hay un problema documental que en muchos supuestos tal vez podría solventarse si se da a los interesados una segunda oportunidad. Por otra, que ante matrimonios presuntamente simulados se anticipe y sustraiga la declaración de nulidad del matrimonio a la vía judicial.

61. En suma, es frecuente y no siempre justificada la denegación de la inscripción. Lo cual conlleva por vía de consecuencia la frustración de los dos objetivos de la caracterización del matrimonio como derecho fundamental: la seguridad jurídica y la continuidad del estado civil. Llama la atención que este prestigioso órgano de la Administración de Justicia actúe subordinando el análisis jurídico a la política de extranjería, siempre coyuntural.

\section{RESUMEN}

\section{MATRIMONIOS CELEBRADOS EN EL EXTRANJERO E INSCRIPCIÓN EN EL REGISTRO CIVIL: PRÁCTICA DE LA DIRECCIÓN GENERAL DE LOS REGISTROS Y DEL NOTARIADO}

En una situación marcada por un incremento del número de recursos planteados ante la DGRN y por la diversificación de modelos familiares, el reconocimiento registral de matrimonios celebrados ante autoridad extranjera en el extranjero experimenta un proceso de restricción seguramente derivado de un temor al fraude.

Palabras clave: matrimonios celebrados ante autoridad extranjera, inscripción registral, reconocimiento y control de validez, tipología, tendencia restrictiva.

\section{ABSTRACT \\ MARRIAGES CELEBRATED ABROAD AND REGISTRATION. THE PRACTICE OF THE DIRECCIÓN GENERAL REGISTROS Y NOTARIADO}

In a context where the recognition of marriages celebrated abroad is increasing extremely as well as matrimonial unions, the DGRN is maximizing its mechanisms to control not only formal but also substantive marriage requirements in order to prevent the access to the Civil Status Register of the cases of fraud.

Keywords: marriages celebrated abroad, register inscription, recognition and validity control, taxonomy, restrictive tendency. 